\title{
TRANSNATIONAL LABOUR RELATIONS: A DREAM OR POSSIBILITY IN SADC?
}

\author{
PAULSMIT*
}

\section{INTRODUCTION}

John Donne's famous saying 'no man is an island, entire of itself' is even more relevant today than it was in 1624 especially in the world of international trade, globalisation, international treaties and the United Nations. Globalisation and the increasing movement of capital and labour across international borders, with the exception of migrant workers who are facing major obstacles in immigration laws, are creating a situation where laws in general and labour laws in particular are obtaining an international character. Internationally, the problem of movement of labour is the asymmetric structure between capital and labour in reference to the freedom of movement. In view of increasing globalisation, the Conventions of the International Labour Organization (ILO) have assumed greater prominence in recent years. Internationalisation and globalisation have had a growing impact in many areas, especially on legal and economic relations. ${ }^{1}$

Contrary to what Mr Robert Mugabe of Zimbabwe might think, no country can isolate itself from the international community. Without taking anything away from the sovereignty of independent states, all countries in the world are part of a larger world community. International bodies like the UN, ILO, EU and others have adopted various international norms and standards to which most countries have agreed, which established minimum international standards with regards to basic universal human rights and worker rights. The Southern African Development Community (SADC) $)^{2}$ is a transnational organisation that has also adopted certain basic norms and standards in its Treaty, Charter on Fundamental Social Rights and various protocols that are applicable to all citizens within SADC.

* PhD (Labour Relations Management). Senior Lecturer, Department of Human Resource Management, University of Pretoria, Republic of South Africa. SADC = Southern African Development Community. This paper is the first of a much larger three year (2013-15) research project on Transnational Labour Relations in SADC under the mentorship of Professor Manfred Weiss.

1 P. A. Smit, Disciplinary Enquiries in Terms of Schedule 8 of the Labour Relations Act 66 of 1995 , Unpublished $\mathrm{PhD}$ thesis, University of Pretoria (2010).

2 Basic facts and figures regarding the composition and aims of the SADC are provided below. 


\section{A. Elements of a transnational labour relations system}

To understand a general structure of the world's industrial relations system, the role of regional powers and transnational actors should be explained in order to perceive the influences of global challenges. ${ }^{3}$

There has been a rapid growth in the role of international agreements and supranational authority over the past forty years that regulate economic, social, communications, environmental and human rights behaviour. ${ }^{4}$ Transnational relations influence world politics in almost every issue-area. Thousands of international non-governmental organisations (INGOs) lobby international regimes and inter-state organisations for their purposes, including financial support. Many multinational corporations with subsidiaries in other countries have annual financial turnovers larger than the gross national product (GNP) of several countries, and create adaptation problems for the foreign economic policies of many states. ${ }^{5}$ The original concept of transnational relations encompasses almost everything in world politics, except inter-state relations. This has led to a situation where many sovereign nation-states were forced to choose a side in establishing their political, economic, social, and cultural relations and operations, which, in itself, again led to regionalism. ${ }^{6}$

One can therefore rightly ask: what is 'transnational'? The term would indicate that it is beyond what is considered to be national, in other words, across national borders. 'Transnational law' is the term commonly used for referring to laws that govern the conduct of independent nations in their relationships with one another. It differs from other legal systems in that it primarily concerns states, rather than private citizens. In other words, it is that body of law that is composed of the greater part of the principles and rules of conduct which states feel themselves bound to observe and, therefore, do commonly observe in their relations with each other. These include:

- the rules of law relating to the function of international institutions or organisations, their relations with each other, and their relations with states and individuals;

- certain rules of law relating to individuals and nonstate entities, so far as the rights and duties of such individuals and non-state entities are the concern of the international community. ${ }^{7}$

Transnational labour relations can be equated with a transnational legal process (TLP) which provides the key to understanding the issue of compliance with

3 A. Aliu 'European Industrial Relations: Transnational Relations and Global Challenges', Munich Personal RePEc Archive (2012).

4 B. A. Simmons, 'Compliance with International Agreements, 1 Annual Review of Political Sciences (1998): 75-93, at 75.

5 T. Risse-Kappen, Bringing Transnational Relations Back in: Non-state Actors, Domestic Structures, and International Institutions, Cambridge University Press (1995).

6 Aliu, supra note 3, at 2.

7 http://legal-dictionary.thefreedictionary.com/Transnational+Law (last accessed 23 June 2014). 
international law. This view immediately raises the following question: why do nation-states and other transnational actors obey international law, and why do they sometimes disobey it $?^{8}$ In order to answer this very important question, three very obvious questions come to light, namely: (1) what is a transnational legal process; (2) where did it come from?; and (3) how does it assist in explaining why nations obey?

Koh sees the transnational legal process as the manner in which theory and practice of public and private actors, nation-states, international organisations, multinational enterprises, NGOs and private individuals interact in a variety of private and public, international and domestic spheres and also how they interpret, enforce and then ultimately internalise the rules of international law. A TLP has four very distinctive features:

1. It is non-traditional.

2. It is non-statist as it also includes non-state actors.

3 . It is very dynamic and not static.

4. It is normative as it not only describes a process but also the normativity of that process. ${ }^{9}$

It would appear that democracies are more likely to comply with international legal obligations, as they share an affinity with international legal processes and institutions. Countries with independent judiciaries are more likely to trust and respect international judicial processes; and political leaders that are accustomed to constitutional constraints on their power in a domestic context are more likely to accept principled legal limits on their international behaviour. ${ }^{10} \mathrm{~A}$ transnational labour relations 'regime' would be a set of structures and norms operating across national borders to buttress national law and practices by either reinforcing national norms or superseding them. ${ }^{11}$ Chayes and Chayes contend that states entering into international agreements will to a certain degree comply with those agreements on three propositions:

1. The propensity to comply is more plausible and useful than the assumption that states will violate treaties whenever it is in their interest to do so.

2. Very often compliance problems do not reflect a deliberate decision to violate international agreements.

3. Complete or strict compliance of treaties is unnecessary and all that is required is an acceptable level of overall compliance to safeguard the interest of the treaty. ${ }^{12}$

8 H. H. Koh (1996) 'Transnational Legal Process', 75 Nebraska Law Review (1996): 181, at 183.

9 Ibid., at 184.

10 Simmons, supra note 4, at 83-4.

11 D. M. Trubek, J. Mosher and J. S. Rothstein, 'Transnationalism in the Regulation of Labor Relations: International Regimes and Transnational Advocacy Networks', 25(4) Law \& Social Inquiry (2002): 1194.

12 A. Chayes and A. Chayes, 'On Compliance', 47(2) International Organization (1993): 175-205, at $176-7$. 
Chayes and Chayes maintain that efficiency, interests and norms all favour treaty compliance. This is mainly because decisions are not free, there is a continuous recalculation of costs vs benefits, and also international treaties are related to states' interests as international law cannot bind sates except with their own consent. As national positions and interests evolve, they will help to induce compliance. The fundamental norm of international law is pacta sunt servanda-treaties are to be obeyed. The compliance with international treaties and law is therefore also a very important normative process.

Chayes and Chayes attribute non-complying behaviour to the following factors:

i. Ambiguity and indeterminacy of treaty language as treaty language varies in its determinacy.

ii. Limitations on the capacity of parties to carry out their undertakings. Apart from a political will to comply, the choices that must be made domestically require scientific and technical judgment which states, especially developing countries, may be lacking.

iii. All treaties require a period of transitions before mandated changes can be accomplished. Changing conditions and underlying circumstances require a shifting mix of regulatory instruments to which state behaviour cannot instantly respond. Treaties are not just 'aspirational', the ultimate goal is to start a process that will over time bring states into greater congruence with treaty ideals. ${ }^{13}$

The traditional model of industrial relations that are limited to the borders of a nation state is increasingly becoming problematic, with the opening of and merging of labour markets, of which the European integration process is a very good example. ${ }^{14}$ The market freedoms enshrined in the Treaty on the Functioning of the European Union (TFEU) have contributed to build up an internal market on a European scale. Transnational enterprises can easily relocate their activities from subsidiaries in one country to those located in another country. ${ }^{15}$ Transnational collective bargaining in European-scale companies has gained increasing relevance over the last years due to the increasing number of European works councils (EWCs) that have been established. Jeremy Waddington describes EWCs as 'a transnational industrial relations institution in

13 Ibid., at 188 .

14 A. Seifert, 'Transnational Collective Bargaining: The Case of the European Union', in K. Malherbe and J. Sloth-Nielsen (eds), Labour Law into the Future: Essays in Honour of D'Arcy du Toit, Juta (2012), pp. 76-96, p. 77.

15 Ibid., p. 78. 
the making'. ${ }^{16}$ European trade unions are also trying to undertake transnational collective bargaining with European-wide companies with European Framework Agreements (EFAs). ${ }^{17}$ EWCs and EFAs have given labour relations in the EU a transnational character. There seems to be increasing support for the establishment of a legal framework for transnational collective bargaining within the EU. The use of international labour standards in domestic law must be based on the legal materials available to states under their own domestic laws. These materials include international customary law, the manner in which a state's constitution articulates with international law. International labour standards provide a rich and authoritative source for the development of labour law at national level that can ensure consistency between the different systems of law and at the same time ensure state compliance with international obligations. ${ }^{18}$

Transnational labour relations can therefore incorporate a set of rules, guidelines and/or principles that are observed by various states. ${ }^{19}$ It is clear that a transnational labour relations system requires input from all actors, namely states, trade unions, employers' associations and the applicable international body through a process of social dialogue.

\section{B. International approaches to transnational labour relations}

The above is a summary of the global and regional framework in which labour law has to evolve. There are various levels at which decisions can be taken that can have an impact on labour relations and employees, namely the level of the undertaking, national or state level, regional level (like SADC) or international level. Should labour relations decisions be taken at all these levels? Should one consider establishing worldwide fundamental social rights? Is there a need for regional rules, such as those of SADC, or should the legislation be limited to national rules at enterprise level $?^{20}$

It would appear that there are currently four basic approaches that are followed internationally when it comes to the implementation of a regional or transnational labour relations system, namely:

1. The Labour Side Agreement of the North American Free Trade Agreement (NAFTA), ensuring that countries enforce their own domestic laws in the areas covered by the agreement. If one member state of NAFTA feels that another is not following its own laws in

16 J. Waddington, European Works Councils: A Transnational Industrial Relations Institution in the Making, Routledge (2011), p. 232.

17 Seifert, supra note 14, p. 86.

18 H. Cheadle, 'Reception of International Labour Standards in Common-law Legal Systems', Reinventing Labour Law (2012): 348-64.

19 For a detailed discussion on the concept of transnational labour relations, see K. Kolben, 'Transnational Labor Regulation and the Limits of Governance', 12(2) Theoretical Inquiries in Law (2011): 403; R. Hoffman, O. Jacobi, B. Keller and M. Weiss (eds), Transnational Industrial Relations in Europe, Hans-Böckler-Stiftung (2000).

20 R. Blanpain, European Labour Law, 10th edn, Wolters Kluwer (2010), p. 45. 
one of the areas covered, the matter is reported to a Commission for arbitration, which can ultimately lead to a judgment.

2. Social dialogue at European level is inter-professional (ETUC, Business Europe and CEEP) and sectoral (more than forty branches of activity). IFAs can be concluded and implemented 'in accordance with the procedures and practices specific to management and labour and the Member States', as found in article 155, paragraph 2 of the TFEU. Inter-professional framework agreements have been reached on, for example, tele-work (2002), stress in the workplace (2004), harassment in the workplace (2009) and inclusive labour markets (2010). These framework agreements are not legally binding on the national actors; their function is to offer the actors on the national scale guidance and enrich their imagination. ${ }^{21}$

3. A more voluntary approach, which can include codes of conduct, guidelines and the adoption of fundamental principles. These are monitored by way of reporting or the soft law approach. These codes can be determined by international bodies like the ILO or the OECD, or can be the result of multinational enterprises establishing codes of conduct. It would appear that this is the approach currently followed by SADC.

4. The integration approach is followed by the European Union. The EU established minimum regional standards that are binding on member states, who must adapt their national legislation to meet the requirements of the minimum regional standard. Minimum standards can be enforced by the European Court of Justice (ECJ), and member states that fail to comply are liable to substantial fines.

\section{Establishment and original aims of SADC}

It is important to have a look at the original aims and establishment of SADC and have a detailed description of the contents of the SADC Charter on Fundamental Social Rights as I argue that the Charter can form the basis of the establishment of a transnational labour relations regime and regional labour standards in the region.

The current members of SADC are: Angola, Botswana, Democratic Republic of Congo, Lesotho, Madagascar, Malawi, Mauritius, Mozambique, Namibia, Seychelles, Republic of South Africa, Swaziland, Tanzania, Zambia and Zimbabwe.

SADC was originally founded in April 1980 as the Southern African Development Coordination Conference (SADCC) by leaders of the so-called Frontline States in Southern Africa. The original aim was to create a mechanism whereby member states could formulate and implement projects of common interest in select areas in order to reduce their economic dependence, particularly, but not only, on the Republic of South Africa. It was conceived as an economic 
dimension of the struggle for liberation from colonial and white minority rule and the economic domination of the sub-region by the apartheid regime in South Africa. ${ }^{22}$

The founders were clear that trade and market integration were not its priorities; the desire was for genuine and equitable regional integration. Trade liberalisation and market integration became part of the SADC common agenda when SADCC became SADC under the Windhoek Declaration and Treaty of 1992. This treaty provided for Regional Economic Communities (RECs) for the different sub-regions of Africa, and SADCC had to be repositioned as the REC for the Southern African sub-region and by including South Africa as a member and prioritising trade liberalisation and market integration. A protocol on trade was signed by eleven member states, excluding Angola, in 1996, providing for the establishment of a free trade area. This protocol became into force in January 2000 when it was ratified by two-thirds of the members. ${ }^{23}$

The main economic objective of SADC is to promote sustainable and equitable economic growth and socio-economic development which will lead poverty alleviation. The main political objectives are to promote common political values and systems through institutions that are legitimate and democratic, and to consolidate, defend and maintain democracy, peace, security and stability. Social and cultural objectives include combatting HIV/AIDS and other communicable diseases.

In pursuit of these objectives, member states are encouraged to ensure the harmonisation of political and socio-economic plans; to develop economic, social and cultural ties; to participate fully in the implementation of SADC projects, developing policies that can lead to the elimination of obstacles to the free movement of people, labour, capital, goods and services; and to promote the development of human resources and also the development, transfer and mastery of technology. Eight areas of cooperation have been identified, each of which is administered by a protocol. A protocol enters into force if it has been ratified by at least two-thirds of the member states and is binding only on those member states that have ratified it. ${ }^{24}$ There is more to SADC than trade liberalisation and market integration.

\section{Summary}

From Table 1, it is clear that the current member states of SADC cover a land area of 554, $919 \mathrm{~km}^{2}$ and in 2010 had a combined population of about 277 million people. This immediately indicates that an acceptable and mutually agreed upon system of transnational labour relations and regional labour standards can be of benefit to a very large number of employees and people.

22 C. Nogongola, 'SADC Law: Building Towards Regional Integration', 2(2) SADC Law Journal (2012): 124.

23 Ibid., at 125.

24 See C. Nogongola, (2008) 'The Legal Framework for Regional Integration in the Southern African Development Community', 8 University of Botswana Law Journal (2008): 3-46. 
Table 1.

\begin{tabular}{|c|c|c|c|}
\hline Indicator & Information & Indicator & Data \\
\hline \multirow[t]{2}{*}{ Member states } & 15 & Total Import & USD $\$ 91,608.15$ (million) \\
\hline & & Total Export & USD $\$ 89,151.33$ (million) \\
\hline Year Established & 1992 & Average Government Debt (2011;\% of GDP) & $40.4 \%$ \\
\hline Land Area & $554919 \mathrm{~km}^{2}$ & Average Life Expectancy (2009) & 55.1 \\
\hline Total Population & 277 million & Average HIV Prevalence Rate (2009) & $12.6 \%$ \\
\hline $\begin{array}{l}\text { GDP Annual Growth Rate } \\
\text { (2011) }\end{array}$ & $5.14 \%$ & Gender (proportion of seats held by women in parliament) - 2011 & $34 \%$ \\
\hline GDP (2010) & USD $\$ 575.5$ Billion & GDP Contribution: Services & $51 \%$ \\
\hline Inflation (2011) & $7.7 \%$ & GDP Contribution: Industry & $32 \%$ \\
\hline Fiscal Balance (2012) & $-3.6 \%$ & GDP Contribution: Agriculture & $17 \%$ \\
\hline
\end{tabular}

Source: FAO (2003) 'State of Forest and Tree Genetic Resources in Dry Zone Southern Africa Development Community Countries' (for the period between 2000 and 2010), Working Paper FGR/41E, Forestry Department, Food and Agriculture Organization of the United Nations. 


\section{SADC CHARTER ON FUNDAMENTAL SOCIAL RIGHTS}

In 2003, SADC adopted a Charter on Fundamental Social Rights which amongst other aims seeks to provide a framework for regional labour standards. It obliges member states to create an enabling environment, consistent with ILO core conventions, to prioritise ILO core conventions, and to take the necessary action to ratify and implement these standards. The Charter further requires member states to create an enabling environment to ensure equal treatment for men and woman, and for the protection of children and young people. ${ }^{25}$ Unfortunately, the Charter cannot be enforced directly, and unlike ILO Conventions, there is no independent supervisory mechanism to call members to account for any breach of the Charter.

The main objectives of this Charter are to:

1. ensure the retention of the tripartite structure of the three social partners, namely: governments, organisations of employers and organisations of workers;

2. promote the formulation and harmonisation of legal, economic and social policies and programmes, which contribute to the creation of productive employment opportunities and generation of incomes, in member states;

3. promote labour policies, practices and measures, which facilitate labour mobility, remove distortions in labour markets and enhance industrial harmony and increase productivity, in member states;

4. provide a framework for regional cooperation in the collection and dissemination of labour market information;

5. promote the establishment and harmonisation of social security schemes;

6. harmonise regulations relating to health and safety standards at workplaces across the region; and

7. promote the development of institutional capacities as well as vocational and technical skills in the region.

It is also important to pay attention to some of the most important articles of the charter that relate directly to labour relations and labour standards:

- Article 3 on universal and basic human rights as proclaimed by the UN Universal Declaration of Human Rights, the African Charter on Human and Peoples' Rights, the Constitution of the ILO and the Philadelphia declaration is to be observed.

- Article 4 on freedom of association and collective bargaining requires member states to create an enabling environment

25 See A. van Niekerk, M. Christianson, M. McGregor, N. Smit and B. P. S. van Eck, Law@work, 2nd edn, Lexis Nexis (2012), pp. 29-30. 
consistent with ILO Conventions on freedom of association, and the right to organise and collective bargaining. This would mean that:

a. employers and workers in SADC shall have the right to form employers' associations or trade unions;

b. employees and employers would also have the freedom of choice to join or not to join a trade union or an employers' association;

c. trade unions and employers' associations can conclude collective agreements according to the national laws of every member state;

d. an independent labour dispute resolution system should be established through a process of tripartite consultation;

e. employees have the right to strike or to participate in other forms of collective action;

f. the organisational rights for representative trade unions shall include access to the employers' premises, deduction of trade union membership fees, right to elect own trade union representatives and union officials, leave for trade union representative and the right to disclosure of information.

- Article 5 on the Conventions of the International Labour Organisation requires member states to establish a priority list of ILO Conventions which shall include Conventions on abolition of forced labour (Nos 29 and 105), freedom of association and collective bargaining (Nos 87 and 98), elimination of discrimination in employment (Nos 100 and 111) and the minimum age of entry into employment (No. 138). Member states must take the necessary steps, as a priority, to ratify and implement the core ILO Conventions. ${ }^{26}$

- Article 6 on the equal treatment of men and women requires that men and women must be treated as equals in all aspects of the work life.

- Article 7 on the protection of children and young people in line with ILO Convention 138 deals with employment age, remuneration of children and young people and vocational training.

- Article 8 addresses the issues of elderly people, retirement age and social benefits for elderly people who do not have a pension but have reached normal retirement age.

- Article 9 covers the treatment of persons with disabilities in the workplace and their access to training and social security. Persons 
with disabilities in the workplace may not be discriminated against in any way and special effort must be made by employers to accommodate such persons in the workplace.

- Under article 10, all employees will have access to social protection, social security benefits and social assistance irrespective the type of employment.

- Under article 11, all member states must strive towards the improvement of living and working conditions of employees by addressing issues like working hours, rest periods, paid leave and maternity leave.

- Under article 12, every employee in SADC has the right to a healthy and safe working environment. The basic working environment and occupational health and safety standards must meet the requirements as set out in ILO Convention No. 155.

- Article 13 requires member states to create an enabling environment so that industrial and workplace democracy is promoted. It also stipulates that employees have the right to be involved in a consultation process and the right to information with regards to restructuring of the workplace and the termination of employment due to operational requirements of the employer.

Member states are required to submit regular progress reports to the Secretariat regarding the implementation of the Charter. Unfortunately, the Charter does not specify what is meant by regular reports nor what steps can be taken against a member state that fails to implement the Charter.

\section{STATUS OF ILO CORE CONVENTIONS IN MEMBER STATES OF SADC}

In 1998 the ILO adopted the Declaration on Fundamental Principles and Rights at Work, which is an expression of commitment by governments, employers' and workers' organisations to uphold basic human values - values that are vital to our social and economic lives. The Declaration commits member states to respect and promote principles and rights in four categories, whether or not they have ratified the relevant Conventions. These categories are:

1. Freedom of association including the right to collective bargaining.

2. The elimination and prohibition of forced or compulsory labour.

3. The abolition and prohibition of child labour.

4. The elimination of discrimination in respect of employment and occupation. ${ }^{27}$ 
Table 2.

\begin{tabular}{lllllllll}
\hline Member & C29 & C87 & C98 & C100 & C105 & C111 & C138 & C182 \\
\hline Angola & 2001 & 1976 & 1976 & 1976 & 1976 & 1976 & 2001 & 2001 \\
Botswana & 1997 & 1997 & 1997 & 1997 & 1997 & 1997 & 1997 & 2000 \\
DRC & 2001 & 1969 & 1960 & 2001 & 1969 & 2001 & 2001 & 2001 \\
Lesotho & 1966 & 1966 & 1966 & 2001 & 1998 & 1998 & 2001 & 2001 \\
Madagascar & 1960 & 1960 & 1998 & 1962 & 2007 & 1961 & 2000 & 2001 \\
Malawi & 1999 & 1965 & 1999 & 1999 & 1965 & 1965 & 1999 & 1999 \\
Mauritius & 2005 & 1969 & 1969 & 1969 & 2002 & 2002 & 1990 & 2000 \\
Mozambique & 1996 & 1996 & 2003 & 1977 & 1977 & 1977 & 2003 & 2003 \\
Namibia & 1995 & 1995 & 2000 & 2000 & 2010 & 2001 & 2000 & 2000 \\
Seychelles & 1978 & 1999 & 1978 & 1978 & 1999 & 1999 & 2000 & 1999 \\
South Africa & 1996 & 1996 & 1997 & 1997 & 2000 & 1997 & 2000 & 2000 \\
Swaziland & 1978 & 1978 & 1978 & 1979 & 1981 & 1981 & 2002 & 2002 \\
Tanzania & 2000 & 1962 & 1962 & 1962 & 2002 & 2002 & 1998 & 2001 \\
Zambia & 1996 & 1996 & 1964 & 1965 & 1972 & 1979 & 1976 & 2001 \\
Zimbabwe & 2002 & 1998 & 1998 & 1998 & 1989 & 1999 & 2000 & 2000 \\
\hline
\end{tabular}

The ILO Declaration of 1998 thereby makes seven core Conventions binding on member states irrespective of whether these Conventions have been ratified or not. There is currently a discussion within the ILO to include the Conventions on health and safety as well as the Convention on a living wage as part of the core labour rights.

Article 5 of the SADC Charter requires member states to establish a priority list of ILO Conventions and specifically to ratify and implement the core conventions of the ILO. Table 2 indicates the fifteen member states of SADC and in which year a particular core convention of the ILO has been ratified. ${ }^{28}$

It is argued that the SADC Charter of Fundamental Social Rights and the seven core ILO Conventions that have been ratified by all member states of SADC can form the basis of a transnational labour relations system in SADC. The main aims of the SADC Charter will not be achieved insofar as concerns the place of work and employees if these core ILO Conventions have no real impact on the shop floor and the lives of employees.

\section{A. The SADC Tribunal}

The SADC Tribunal was established in 1992 by article 9 of the SADC Treaty as one of the institutions of SADC. The Summit of Heads of State or Government, which is the Supreme Policy Institution of SADC pursuant to article 4(4) of the Protocol on Tribunal, appointed the Members of the Tribunal during its Summit of Heads of State or Government held in Gaborone, Botswana on 18 August 2005. The inauguration of the Tribunal and the swearing in of the Members took place on 18 November 2005 in Windhoek, Namibia. ${ }^{29}$

28 Ibid.

29 http://www.sadc-tribunal.org (last accessed 30 January 2013). 
The SADC Tribunal is regulated by the Protocol on the SADC Tribunal. Under international law, the Tribunal is viewed as an international court similar to the European Court of Justice, and it is a permanent court. According to article 16 of the SADC Treaty, the main objective is to ensure that member states adhere to the provisions of the Treaty and other subsidiary instruments. The Tribunal should ensure that member states do not fall foul of SADC law. ${ }^{30}$

The Tribunal is not a human rights court per se but has jurisdiction to entertain human rights matters; it is also not a criminal court and does not have criminal jurisdiction. Any person, natural or juristic, can bring a matter before the Tribunal alleging a violation of SADC law by a member state. The working languages of the Tribunal are English, French and Portuguese. Decisions of the Tribunal are to be enforced in member states in accordance with member states' laws and rules of civil procedure for the enforcement of foreign judgments.

The decisions of the Tribunal are final and binding upon the parties and there is no appeal against its decision. Should it appear that a party has no intention to comply with the Tribunal's decision, the Tribunal will report the matter to the Summit, which is responsible for the overall policy direction and control of functions of the Community, ultimately making it the policy-making institution of SADC. It is made up of all SADC Heads of States or Government. The Summit is under a legal duty to take 'appropriate action' against the recalcitrant party. ${ }^{31}$

Zimbabwe became bound by the SADC Treaty and all its institutions after President Mugabe signed it in August 1992 and it was ratified by the Zimbabwe parliament. Numerous matters were brought against the government of Zimbabwe and President Robert Mugabe by individuals to the SADC Tribunal for adjudication and the Tribunal has made several judgments against Zimbabwe.

The SADC Tribunal held with regards to the case of Campbell v Zimbabwe $e^{32}$ as follows:

- By unanimity, the Tribunal has jurisdiction to entertain the application.

- By unanimity, the Applicants have been denied access to the courts in Zimbabwe.

- By a majority of four to one, the Applicants have been discriminated against on the ground of race.

- By unanimity, fair compensation is payable to the Applicants for their lands compulsorily acquired by the Respondent.

The SADC Tribunal further held that Zimbabwe had breached the SADC Treaty.

30 'The SADC Tribunal in 20 Questions' (2), http://www.sadc-tribunal.org (last accessed 30 January 2013).

31 The meaning of 'appropriate action' and its impact or effectiveness is not clear.

32 William Campbell and Another v Republic of Zimbabwe, SADC (T) 03/2009 (hereinafter Campbell case). 
President Robert Mugabe and the Zimbabwe government have refused to recognise the jurisdiction of the SADC Tribunal. In February 2009, the Deputy Chief Justice of Zimbabwe stated that the SADC Tribunal lacked jurisdiction to hear and determine the Campbell case. During his birthday celebrations, President Robert Mugabe described the SADC Tribunal's decision as 'nonsense' and 'of no consequence', and stated that land distribution will continue and will not stop as Zimbabwe's land issues are not subject to the SADC Tribunal. ${ }^{33}$ Campbell, a white farmer, brought his case to the SADC Tribunal after his farm was repossessed by the Zimbabwe government, without any compensation, as part of the government's land reform process. Campbell had no recourse to the judicial system within Zimbabwe.

Tragically the SADC Tribunal has been proven to be ineffective at enforcing its judgment against Zimbabwe. The judgment in Campbell $v$ Zimbabwe was adjudicated on the premise of international law, contained elements of human rights and the SADC Tribunal had authority to hear the case, but it clearly illustrates how difficult it is to enforce judgments made by an international tribunal where they involve a sovereign nation. ${ }^{34}$

After these judgments and rulings against the Zimbabwe government, ${ }^{35}$ the Tribunal was de facto suspended at the 2010 SADC Summit. This decision was confirmed by the Council of Ministers of SADC at an extraordinary meeting in Windhoek on 20 May 2011 where the following was in effect decided:

i. the non-reappointment of members of the Tribunal whose term of office expired on August 31, 2010;

ii. the non-replacement of members of the Tribunal whose term of office will expire on October 31, 2011;

iii. the dissolution of the Tribunal in its present form which is expressly barred from hearing any new or pending cases; and

iv. the establishment of a new Tribunal, with a different jurisdiction and a new membership, after the Ministers of Justice/Attorneys General have amended the relevant SADC legal instruments e.g. the SADC Treaty and the Protocol on Tribunal (Protocol) and submitted a progress report to Summit in August 2011 and the final report to Summit in August 2012. ${ }^{36}$

33 J. Johnson, 'Enforcing Judgments in International Law', JD Supra Law News, 24 October 2011.

34 Ibid., p. 21.

35 It was especially the Campbell ruling of the Tribunal, supra note 32, that stipulated that the respondent, Government of Zimbabwe, is in breach of a former ruling of the Tribunal and in contempt of the Tribunal that led to the decision of the SADC summit in 2010.

36 Ariranga Pilay (former president of the SADC Tribunal), 'SADC Tribunal Dissolved by Unanimous Decision of SADC Leaders', Speech delivered at a Law Society of Namibia workshop, Windhoek, 22 July 2011. 
On 17 August 2012 in Maputo, Mozambique, the SADC Summit addressed the issue of the suspended SADC Tribunal. The SADC Summit resolved that a new Tribunal should be negotiated and that its mandate should be confined to interpretation of the SADC Treaty and Protocols relating to disputes between member states. ${ }^{37}$ This in fact means that individual citizens of member states would be precluded from approaching the SADC Tribunal.

The suspension of the SADC Tribunal could create the impression that SADC in itself is nothing but a puppet in the hands of some powerful leaders within SADC, and that some leaders within the SADC community - like President Robert Mugabe of Zimbabwe - have the ability to force their will and/or views onto other heads of state. SADC member states have made no effort to put any pressure on the Zimbabwe government to adhere to the judgment of the SADC Tribunal but instead opted for the suspension of the Tribunal.

The compliance with international obligations is not properly monitored within SADC and currently no penalties exist for non-compliance. ${ }^{38}$ Because of this, it is easier for member states to ignore international obligations, and there is no political will to enforce sanctions against members who violate their obligations under the SADC Treaty. There is no proper regulatory framework to ensure that member states adhere to the provisions and standards of the SADC Treaty, and where there is failure to do so, sanctions and penalties are rarely enforced..$^{39}$ On 16 August 2013, the SADC Lawyers' Association issued a press statement in which it expressed its concern with the continued suspension of the Tribunal, which negatively impacts on the rights of SADC citizens not only to access justice but also to seek effective legal remedies. The limitation on the powers of the Tribunal, in the proposed new protocol of the SADC Tribunal, impacts negatively not only on human rights but also on the trends towards regional courts, the SADC integration agenda and investor confidence ${ }^{40}$ Currently no alternative formal or semi-formal system of monitoring or enforcement of SADC protocols, the SADC Charter and/or SADC law has been established.

The consequences of the Campbell matter and the subsequent suspension of the SADC Tribunal is the most dramatic rejection of transnationalism not only in the SADC region but also in Africa. The question can rightly be asked if the Charter and SADC Treaty is only a paper tiger or whether it has any impact whatsoever in reality. Without an independent monitoring mechanism, like the SADC Tribunal, that can also enforce decisions, treaties, charters and protocols

37 As on 30 January 2013 a new Tribunal has not yet been established and currently there is no mechanism to enforce and ensure compliance with SADC law, the Charter and/or protocols.

38 G. Erasmus, 'Is the SADC Trade Regime a Rules-based System?', 1 SADC Law Journal (2011): $17-34$.

39 R. Jere, 'Labour Standards \& Foreign Direct Investment in SADC: A Case Study of Malawi', in O. C. Dupper, M. Olivier and A. Govindjee (eds), The Role of Standards in Labour \& Social Security Law: International, Regional and National Perspectives, Juta (2013), pp. 249-50.

40 SADC Lawyers' Association statement on SADC Tribunal, 16 August 2013, available at http://www.igd.org.za/.../sadc.../5328-sadc-lawyers-association-statement-on-sadc-tribunalregional-governance-issues (last accessed 17 November 2013). 
on member states, SADC will be nothing more than a tea club where heads of governments get together for a nice meal.

\section{B. Transnational labour regulation in SADC based on the EU experience}

Having had a look at the EU 'experiment' with regards to the integration of labour policies on an EU level and the structures of SADC, the SADC Charter on Fundamental Social Rights, as well as the unfortunate demise of the SADC Tribunal, it would seem that the following should be considered by SADC:

\section{Regional treaties}

The main aim of transnational labour regulation should be to promote social justice across national borders in a regional context, like the EU or SADC. The social and employment dimensions of regional economic treaties, such as those of the EU, have broadened the scope of labour law to now include previously excluded groups in all member states. Based on these dimensions, the EU has followed an open method of coordination and social dialogue against the background of fundamental rights. In this regard, Hepple stated the following:

Synchronised co-ordination (not convergence) of social and employment policies, through a social dialogue between the main interests groups, offers an important, even if not wholly adequate, means of overcoming competition for capital among national and regional workforces. Fundamental rights based on a European consensus about the essential values shared by the governments and peoples of the region provide the necessary basic principle for these developments. ${ }^{41}$

What is currently lacking in this form of European integration is collective labour law. The current EU treaties are a product of the negotiations between governments advancing their own national interests rather than a supra-national ideal. Collective bargaining across national borders in the EU is very limited or almost non-existent, and there has been no democratic participation in this process by all the social partners; however, these treaties do form a framework for reconciling market freedoms with social and labour rights under the rule of law. Seifert maintains that transnational collective bargaining within the EU will be effective only if the social partners promote the harmonisation of labour laws of the member states by concluding collective agreements at European level. ${ }^{42}$

Given the demise of the SADC Tribunal, it is also questionable whether SADC 'law', fundamental social and labour rights, SADC protocols, the SADC Charter and the SADC Treaty can be enforced in member states. Given the huge differences on an economic development level, the rule of law, levels of

41 B. Hepple, Labour Laws and Global Trade, Hart Publishing (2005), p. 272.

42 Seifert, supra note 14, p. 95. 
social development, free market principles and democracy that exist among the member states of SADC, it is doubtful that a system of synchronised coordination through social dialogue will be effective within SADC. The SADC Charter and the various protocols adopted by SADC member states can provide a framework for social and labour rights on a regional level; however, there seems to be a lack of willingness and the political will amongst certain member states to adhere to these instruments -Zimbabwe and Swaziland being prime examples.

\section{Transnational corporations and international framework agreements (TNCs and IFAs)}

Numerous TNCs and IFAs in the EU have a culture of corporate social responsibility, and have adopted voluntary codes of conduct and collective agreements, as well as best practice principles. ${ }^{43}$

TNCs and IFAs usually provide better wages, working conditions and social security benefits, as they tend to be concentrated in capital-intensive, highly skilled professions and employ effective managerial and organisational techniques. The problem with the codes of TNCs and IFAs is ineffective implementation in host countries, coupled with local workers' having almost no means of reporting non-compliance. There is also very often an absence of monitoring to see that the TNC actually follows the code, and that the IFA is implemented. Corporate codes and IFAs are private sector initiatives, and tend to be more selective in their choice of human and labour rights than public regulatory frameworks.

In the SADC context, the codes of TNCs and principles of IFAs can have a spill-over effect in domestic firms. For these codes of TNCs and the IFAs to have any real impact on the creation of regional labour standards, they should specify ILO core standards as a minimum. The national laws of each member state should also place TNCs and the parties in IFAs under legal obligation to observe their own codes, and regional conventions like the SADC Treaty, the SADC Protocol and the SADC Charter should also be strengthened and directed at TNCs and IFAs. ${ }^{44}$ In addition, there should be an independent monitoring system and an effective national and regional complaints mechanism within SADC to ensure that TNCs and IFAs comply with their own codes. The now defunct SADC Tribunal could have fulfilled such a role.

\section{Empowering local actors}

Local actors, such as unions, women's social movements, consumers, students and human rights activists in the EU have the necessary skills and knowledge to create awareness of the abuses of labour rights. Their role in the creation of public awareness of human rights, social rights and labour rights in the EU can never be underestimated.

43 Hepple, supra note 41, p. 272.

44 See ibid., chapter 3 and pp. 272-3. 
Within SADC, the strong trade union movement, as well as other human rights activist groups in South Africa, has played a major role in the dismantling of apartheid, and continues to have a major impact on the establishment of social and labour rights in South Africa. The political environment within South Africa is such that local actors can be a positive influence on the establishment of regional labour standards within SADC, as stated above. The same cannot be said, however, for the local actors in Zimbabwe, Swaziland, Madagascar and the DRC. These countries are marked by either internal conflict and war or governments that do not recognise trade union rights, and there is no real democracy.

The empowerment of the local actors in all member states of SADC can contribute towards the establishment of regional labour standards for SADC, if the local actors can operate freely in each country, without fear of oppression or imprisonment, in a free, democratic society.

\section{ILO standards}

Another way of creating transnational or regional labour standards is to ensure the application of international labour standards set by the ILO. All SADC member states have ratified the core conventions of the ILO, but ratification does not mean implementation.

In recent years, the ILO has attempted to revitalise international labour standards by promoting the 1998 Declaration of Fundamental Principles and Rights at Work, revising labour standards to ensure a more integrated and coherent approach with its campaign for 'decent work'. For ILO standards to be effective in SADC, it should not only focus on and be limited to those employees in formal employment, but should also include workers in the informal sector. It is also suggested that the cosmetic distinction between recommendations and conventions be replaced by a few framework conventions that provide principles, including a code of practice that is directed at very specific groups. ${ }^{45}$ SADC should also follow a rights-based approach to implementing these principles by making compliance and implementation a condition of membership of SADC. In addition, there should be a complaints-based enforcement mechanism. Persuasion and a soft-law approach for member states to comply with and implement ILO standards within the SADC region will not work unless there is ultimately a sanction that can be invoked.

\section{CONCLUSION AND RECOMMENDATIONS}

The EU is very different to SADC in almost every respect, but there are a number of lessons that SADC might find useful:

1. The EU still recognises the differences between member states, and the EU system accommodates these differences. If a system of regional labour standards is developed for SADC, it must take 
cognisance of differences between countries in terms of culture, language, history, the legal system, etc.

2. The system that has been designed for the EU and that is currently in place is a uniquely European system and cannot be transferred to SADC as is. SADC must not try to replicate the EU system of regional labour standards.

3. The proposed system of transnational labour relations for SADC should be a combination of the following:

a. The SADC Treaty, certain SADC protocols and the SADC Charter should be adapted, extended and strengthened to make provision for minimum regional labour standards. This treaty on minimum regional labour standards should include, as a bare minimum, requirements of the ILO core standards, the UN Declaration of Human Rights and employees' rights at work. The domestic incorporation of the SADC Treaty, SADC Charter and SADC protocols into national laws can ensure ease of compliance by member states.

b. A code of best practice for TNCs and IFAs should be established, providing minimum labour standards for any TNC and IFA that wants to establish business enterprises in any SADC member state.

c. The local actors in all SADC member states should be empowered through a process of training, so as to provide them with the necessary skills, knowledge and expertise to create public awareness of human rights, social rights and labour rights. The local actors in each member state can play a significantly positive role in ensuring that governments adhere to the minimum regional labour standards.

d. An independent monitoring system that brings governments, employers, TNCs and IFAs to task for failure to comply with minimum regional standards should be established. The SADC Tribunal should become operational as soon as possible, and its mandate should be extended so that it can also act as a labour standards watchdog. The new Tribunal should have the power to take appropriate steps not only against employers or TNCs, but also against governments. These powers could include imposing fines on transgressors.

A regional labour standards regime or transnational labour relations system for SADC is possible, and it could assist in providing certain minimum protections and labour rights for millions of people. It is, however, of the utmost importance to involve all role players from all the member states. These must include not only governments and politicians, but also employers' associations, trade unions and other local actors. Rules are needed at the appropriate levels, so that economic 
principles and justice go hand in hand, and the standards and the issues at stake have a transnational or supra-national character. Thus, SADC must have its own, unique social policy and, consequently, also its own fully fledged labour relations system. SADC must move away from being a facilitating authority to being an entity that will lead in creating standards and mechanisms that can be of benefit to all SADC citizens, and become a truly transnational actor. 